\title{
RELATIONSHIPS OF PRIMARY AND SECONDARY WHEAT YIELD COMPONENTS
}

\author{
Murilo Vieira Loro ${ }^{1}$, Ivan Ricardo Carvalho ${ }^{1}$, José Antonio Gonzalez da Silva ${ }^{1}$, Natã Balssan \\ Moura $^{1}$, Danieli Jacoboski Hutra ${ }^{1}$, Francine Lautenchleger ${ }^{1}$, Velci Queiróz de Souza ${ }^{1}$ \\ ${ }^{1}$ Northwestern Regional University of the State of Rio Grande do Sul, Ijuí - Rio Grande do Sul State, Brazil \\ E-mails: loro@gmail.com, carvalho.irc@gmail.com, silva@gmail.com, moura@gmail.com, hutra@gmail.com, \\ lauter@gmail.com,souza@gmail.com
}

\begin{abstract}
The aim is to improve production techniques, so the objective of the study is to verify the change in the productivity dynamics of ears contained in the main stems and tillers related to sowing densities and dual purpose wheat cultivars. The experiment was carried out in Frederico Westphalen, Rio Grande do Sul State, Brazil. The design used was randomized blocks organized in factorial scheme, with five wheat cultivars, five density managements, arranged in three repetitions. In the analysis of variance, interaction for cultivar and density was observed for all variables analyzed, except for ear length in the main plant, tiller ear length, and grain mass per tiller; indicating that the interaction between both collaborated to obtain the results. The cultivars BRS Tarumã, BRS Figueira and BRS Guatambu showed themselves to be able to compensate the production in higher densities, increasing the values of some variables analyzed. All yield components show positive correlations.
\end{abstract}

Keywords: Triticum aestivum, reserve reallocation, plasticity, fertile tillers

\section{ASSOCIAÇÕES DOS COMPONENTES DO RENDIMENTO PRIMÁRIO E SECUNDÁRIO DO TRIGO}

\section{RESUMO}

Com o objetivo de aprimorar as técnicas de produção, o estudo visa verificar a mudança na dinâmica da produtividade das espigas contidas nos colmos e perfilhos principais em função das densidades de semeadura e cultivares de trigo de duplo propósito. O experimento foi realizado em Frederico Westphalen, Rio Grande do Sul, Brasil. O delineamento utilizado foi de blocos ao acaso, organizados em esquema fatorial, com cinco cultivares de trigo, cinco manejos de densidade, dispostos em três repetições. Na análise de variância observou-se interação cultivar e densidade para todas as variáveis analisadas, exceto comprimento da espiga na planta principal, comprimento da espiga do perfilho, e massa de grãos por perfilho; indicando que a interação entre ambas 
colaborou para a obtenção dos resultados. As cultivares BRS Tarumã, BRS Figueira e BRS Guatambu mostraram-se capazes de compensar a produção em maiores densidades, aumentando os valores de algumas variáveis analisadas. Todos os componentes do rendimento mostram correlações positivas.

Palavras-chave: Triticum aestivum, realocação de reserva, plasticidade, perfilhos férteis

\section{INTRODUCTION}

Wheat (Triticum aestivum L.) is an annual grass grown worldwide. It exhibits significant importance in human and animal nutrition, constituting one of the main components of the diet in most countries (CARVALHO et al., 2016). This cereal stands out nutritionally, and is also an important tool for maintaining a sustainable and efficient no-till system, as it is integrated in rotation/succession systems with soybean and corn crops in the producing regions of southern Brazil (PELEGRIN et al., 2016).

On a global scale, the largest producer of wheat is the European Union, which holds $20 \%$ of production. Among the countries of America, Argentina stands out as the largest producer with 71.3\%, followed by Brazil with $17.3 \%$ (USDA, 2018). Brazil is not self-sufficient in crop production (KEHL et al., 2016), in the year 2017 it reached 5.4 million tons of grain produced, supplying only $49.71 \%$ of the internal demand for this cereal. Therefore, this factor makes the country a major importer of wheat grains, generating expenditures that could be met internally with increased productivity. The projection for Brazilian cereal production, according to the Ministry of Agriculture, Livestock and Supply (2019), for the 2028/29 crop season will be 7.2 million tons, with an average consumption estimate of 14.3 million tons of grains.

Several environmental factors influence both management and initial establishment of wheat crop in the field, being also responsible for its yield (AISENBERG et al., 2016). According to Gayler et al. (2014), the productive efficiency of wheat is strictly related to the interaction of a series of factors, among them, seed genetics, soil fertility, cultural management to which the crop was established, and to the edaphoclimatic conditions of the location.

Among the components of the crop yield, there are the number of grains per ear, average grain mass and number of ears per unit area, which are dependent on the number of fertile tillers per area and constitute the final expression of the crop yield (MUNDSTOCK, 1999; STEDUTO, 
2012). In Brazil, one of the main reasons for the low yield of wheat crops has been attributed to the small participation of tillers in the final expression of yield (MUNDSTOCK, 1999), related to the lack of a criterion for choosing an adequate seeding density, which defines the final population density of plants in the field. The production of tillers is a fundamental process when it comes to determining the grain yield of wheat, since it is directly linked to the expansion of the leaf area during the initial stages of crop development (ROY \& GALLAGHER, 1985).

The population density of plants directly impacts the number of ears per unit area, significantly increasing competition between plants for available resources such as water, light and nutrients (OLSEN et al., 2006). As a consequence of this process, the other components of the yield such as the number of grains per ears and the grain mass are affected (LLOVERAS et al., 2004; OZTURK et al., 2006).

The expression of the productive potential in wheat is dependent on the genotype. Thus, the optimum density level that determines the maximum grain yield may not be directly related only to the emission of tillers (BENIN et al., 2003). In the study conducted by Valério et al. (2008), wheat genotypes that showed reduced tillering potential were more dependent on sowing density. Thus, if an adequate seeding density were determined, it would be possible to obtain the maximum grain yield, with the ideal balance of yield components. In this context, the objective is to improve production techniques, so the study aims to verify the change in the productivity dynamics of ears contained in the main stems and tillers related to the sowing densities and dual purpose wheat cultivars.

\section{MATERIAL AND METHODS}

The experiment was carried out in the 2013/2014 crop season at the Federal University of Santa Maria, in Frederico Westphalen, state of Rio Grande do Sul, Brazil (27 39'56" S, 53 42'94"W, at $190 \mathrm{~m}$ altitude. The site is classified as aluminofferric Red Latosol (Oxisol), and the region climate as subtropical Cfa, according to Koppen (ALVARES et al., 2013). The design used was randomized blocks, organized in a 5x5 factorial scheme with five wheat cultivars (BRS Tarumã, BRS Umbu, BRS Figueira, BRS Guatambu, and BRS 277), five density managements $(75,150,225,300$, and 375 seeds per square meter), arranged in three repetitions. The experiment was based on the direct seeding system, the base fertilization used was $400 \mathrm{~kg} \mathrm{ha}^{-1}$ of NPK in the formulation (10-20-20), for top dressing $135 \mathrm{~kg} \mathrm{ha}^{-1}$ of nitrogen was applied in the amidic form in 
stadiums V4 and V6. The experimental unit consisted of 12 lines of two meters in long spaced by 0.17 meters. The control of weeds and insect pests was carried out preventively in order to minimize the biotic effects on the results of the experiments. The characters of interest were measured in the useful area of each experimental unit, which was composed of 4.08 square meters. The measured characters were as follows: ear length per main plant (ELP, $\mathrm{cm}$ ), ear mass per main plant (EMP, g), number of grains per main plant (NGP, unit), grain mass per main plant (GMP, g),

tiller ear length (TEL, cm), tiller ear mass (TEM, g), number of grains per tiller (NGT, unit), grain mass per tiller (GMT, g).

The data obtained were submitted to the assumptions of the statistical model, normality, homogeneity and additivity of the model. Afterwards, analysis of variance at 5\% probability was used to identify the presence of interaction between cultivars $x$ sowing densities. The qualitative factor cultivars were broken down to simple effects through the 5\% Tukey probability matrix in the presence of interaction, for the quantitative factor, linear regression with adjustment of the polynomial degree to $5 \%$ probability was used by the $\mathrm{T}$ test for each qualitative factor level. The characters that showed no interaction were split into the main effects by Tukey at 5\% probability for the effects of cultivars and linear regression with adjustment of the polynomial in general for the effects of density. Afterwards, linear correlation was used in order to identify the association between characters with significance based on $5 \%$ by the $\mathrm{T}$ test.

\section{RESULTS AND DISCUSSION}

In the analysis of variance (Table 1.), interaction for cultivar and density was observed for all variables analyzed, except for ear length in the main plant (ELP); tiller ear length (TEL), and grain mass per tiller (GMT), indicating that the interaction between both collaborated to obtain the results.

It was observed (Figure 1.) in the densities of 75 and 150 seeds per square meter that in the lowest density the cultivars BRS Umbu, BRS Guatambu and BRS Figueira presented high values of ear mass of the main plant (EMP), which can be explained by virtue of less tillering capacity. According to Carvalho et al., (2015) plants with less tillering capacity tend to have a larger main stem diameter and this is directly correlated with the grain mass per ear. 
Table 1. Summary of the analysis of variance for the five wheat genotypes at five sowing densities. Frederico Westphalen, Rio Grande do Sul State, Brazil, 2013/14.

\begin{tabular}{llllllllll}
\hline Source of variation & DF & \multicolumn{2}{l}{ Mean square } \\
\cline { 3 - 10 } & & ELP & EMP & NGP & GMP & TEL & TEM & NGT & GMT \\
\hline BLOCK & 23 & $13.270^{*}$ & $2.173^{*}$ & $729.847^{*}$ & $1.308^{*}$ & $9.341^{*}$ & $0.726^{*}$ & $290.863^{*}$ & $0.401^{*}$ \\
CULTIVAR & 4 & $155.978^{*}$ & $1.354^{*}$ & $814.212^{*}$ & $1.258^{*}$ & $61.376^{*}$ & $0.581^{*}$ & $613.381^{*}$ & $0.371^{*}$ \\
DENSITY & 4 & $1.709^{*}$ & 0.029 & 6.508 & 0.015 & 0.215 & 0.051 & 8.221 & 0.011 \\
CXD & 16 & 0.704 & $0.190^{*}$ & $82.324^{*}$ & $0.099^{*}$ & 0.621 & $0.089^{*}$ & $43.812^{*}$ & 0.028 \\
ERRO & 553 & 0.661 & 0.087 & 30.597 & 0.035 & 0.599 & 0.032 & 21.832 & 0.023 \\
\hline
\end{tabular}

ELP: main ear length, EMP: ear mass of the main plant, NGP: number of grains of the main plant, GMP: grain mass of the main plant, TEL: tiller ear length, TEM: tiller ear mass, NGT: number.
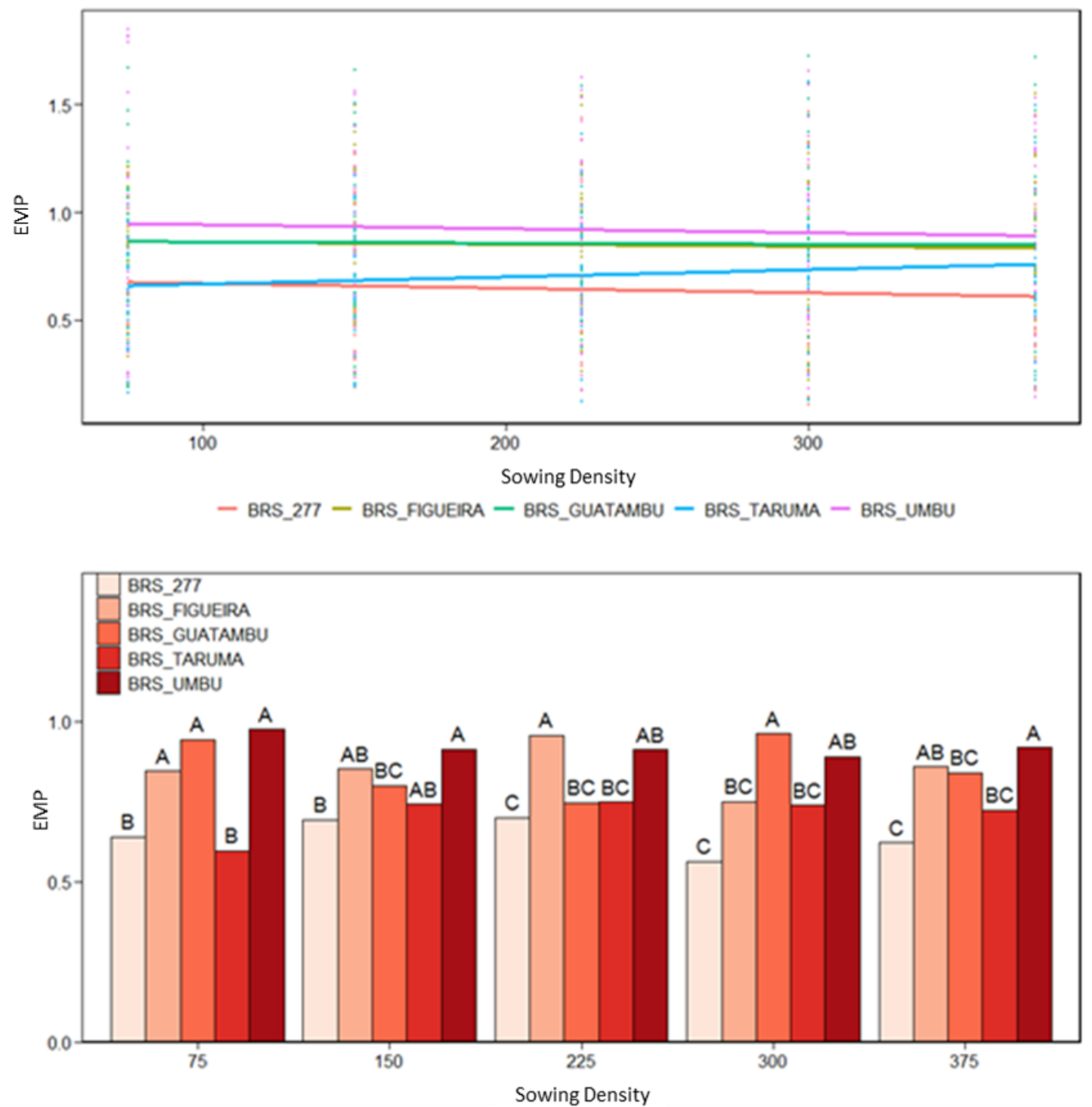

Figure 1. Effect of density on the ear mass in the main plant and cultivar behavior. BRS $277 \mathrm{y}=$ $1.573 \mathrm{R}^{2}$ : 0.01; BRS Figueira $\mathrm{y}=2.365 \mathrm{R}^{2}$ : 0.04; BRS Guatambu $\mathrm{y}=0.05 \mathrm{R}^{2}$ : 0.05; BRS Tarumã $y=0.134 R^{2}: 0.03$; BRS Umbu $y=0.304 R^{2}$ : 0.01. Frederico Westphalen, Rio Grande do Sul State, Brazil, 2013/14. 
According to Valério et al. (2008), all genotypes with reduced tillering show superiority in average ear mass. However, the cultivars BRS Tarumã and BRS 277 expressed lower results for ear mass in the main plant, a result that can be related to the greater tillering capacity of these genotypes. Carvalho et al., (2015) found that the largest number of fertile tillers has a direct negative relationship with the grain mass per ear. Valério et al. (2008) states that the reduction in the ear grain mass is related to the potential of tillering of the genotypes, that is, thus having a high production of ears causing competition for photoassimilates reducing the ear mass.

For densities 225 and 375 seeds per square meter, the cultivars BRS Figueira and BRS Umbu showed superior results of ear mass in the mother plant, which can be attributed to the greater phenotypic plasticity of both genotypes for this character. On the other hand, BRS Tarumã, BRS Guatambu and BRS 277 cultivars showed lower ear masses in the main plant. In addition, the cultivars BRS Umbu and BRS Guatambu showed superiority for ear mass in the main plant at a density of 300 seeds per square meter.

The cultivars BRS 277, BRS Figueira and BRS Tarumã, due to their greater tillering, showed ear mass in the lower main plant. It was found that genotypes BRS Tarumã and BRS 277, regardless of densities, showed lower values for the analyzed character, justified by the greater tillering potential of the two cultivars, occurring photoassimilated competition. Just as the BRS Umbu genotype exhibited higher ear masses of the mother plant, less tillering capacity was attributed, diverging from Martin et al. (2010), where the cultivar BRS Figueira exhibited a higher ear mass than BRS Umbu, however the latter showed a greater hundred grain mass. According to Valério et al. (2008), the compensatory effect of genotypes with reduced tillering potential is the result of a greater grain mass per ear. In addition, it is clear that all genotypes, except BRS Tarumã, indicated a reduction in the average grain mass as the density increased due to intraspecific competition. The cultivar BRS Tarumã showed a small increase in grain mass according to the increase in density. Wheat cultivars with high tillering capacity are not associated with high seed density, indicating that when subjected to higher densities they present a decrease in tillering due to competition for environmental factors. Thus, because this genotype has high tillering at lower densities, there is greater intraspecific competition, reducing the ear mass of the main plant. At high densities, the number of tillers is reduced, and the intraspecific competition of plants with a higher number of tillers is greater than that of plants with less tiller production. Tavares et al. (2014) 
stated that there is greater competition between the plant itself and between the plants, in low and high sowing density, respectively.

At density of 75 seeds per square meter (Figure 2.), cultivars such as BRS Umbu, BRS Guatambu, BRS Figueira and BRS 277 showed superiority for number of grains per ear in the main plant (NGP), which can be explained by the lower tillering capacity. At density of 150 seeds per square meter, in addition to the cultivar Tarumã, the Guatambu genotype also showed lower numbers of grains per ear in the main plant. Just as BRS Guatambu had a lower number of grains than the other cultivars at density 225 seeds per square meter. However, only BRS Figueira and BRS Umbu showed superiority in the number of grains at high densities of 300 seeds per square meter, however, when 75 seeds per square meter were added, except BRS 277, all genotypes show superiority for number of grains.
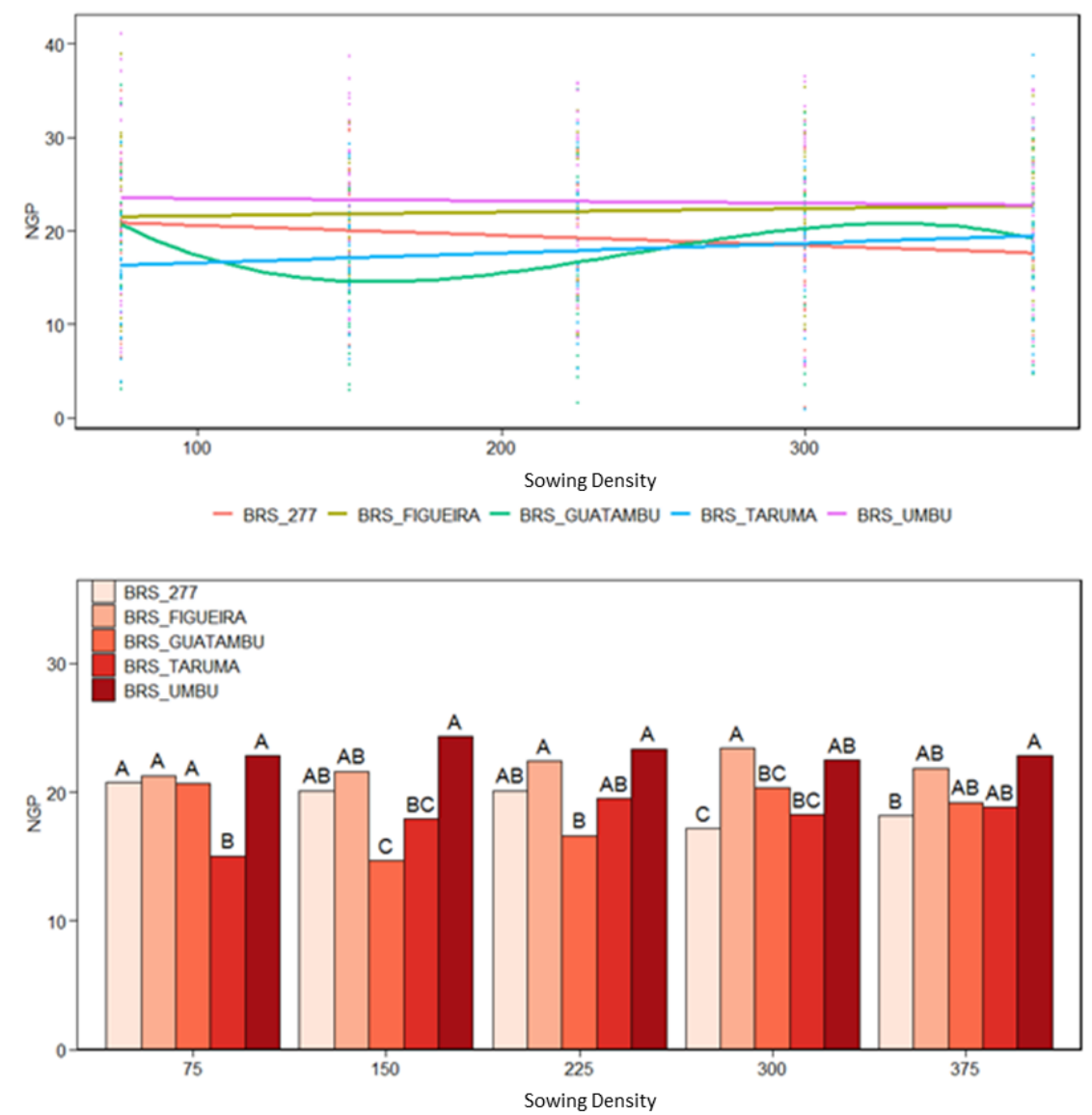

Figure 2. Effect of density on the number of grains in the main plant and cultivar behavior. BRS $277 y=36.251 R^{2}: 0.04$; BRS Figueira $y=19.228 R^{2}: 0.01$; BRS Guatambu $y=41.270-$ $0.0399 \mathrm{x}+0.001 \mathrm{x}^{2}-0.000002 \mathrm{x}^{3} \mathrm{R}^{2}: 0.08$; BRS Tarumã $\mathrm{y}=18.702 \mathrm{R}^{2}: 0.05$; BRS Umbu $\mathrm{y}=16.038 \mathrm{R}^{2}$ : 0.01. Frederico Westphalen, Rio Grande do Sul State, Brazil, 2013/14. 
Thus, it is noticed that the cultivars BRS Umbu and BRS Figueira indicate superiority in the number of grains regardless of the density used, showing compensatory capacity for the number of grains in different environments. It can be attributed to cultivars with low tillering capacity when compared to the others in the study. The same result was obtained by Martin et al. (2010) where BRS Umbu and BRS Figueira presented the highest average number of grains per ear.

The cultivars BRS Umbu and BRS 277 reduced the number of grains per plant since there was an increase in density. BRS Tarumã and Figueira showed an increase in the number of grains per plant when there was an increase in density. However, BRS Guatambu showed variation, reducing the number of grains per plant at lower densities and an increase at higher densities.

Analyzing the behavior of the genotypes (Figure 3.), it was noticed that for the variable grain mass per main plant, in the densities of 225 and 375 seeds per square meter. The wheat cultivars BRS Figueira and BRS Umbu show superior results, the latter highlighted in the density of 150 seeds per square meter due to the low compensatory capacity of tillers reducing intraspecific competition. According to Valério et al. (2008), high sowing density is linked to the reduction of tillers per plant. When there were 75 seeds per square meter, it was found that, in addition to the BRS Umbu genotype, BRS Guatambu showed higher values. However, the BRS Umbu, BRS Guatambu and BRS Figueira genotypes showed a higher grain mass per main plant than the other genotypes at a density of 300 seeds per square meter.

The cultivar BRS Umbu showed superior results regardless of the density of seeds used, however, there was a reduction in the grain mass per main plant as the density increased. The opposite is observed in the BRS Figueira and BRS Tarumã genotypes, where there was a decrease in the grain mass per main plant due to the increase in final density. BRS Guatambu presented an oscillation in the result of the analyzed variable, presenting a greater adaptation when submitted to high or low densities.

For the cultivars BRS Umbu, BRS Guatambu and BRS Figueira, evaluated at the density of 75 seeds per square meter, BRS Umbu and BRS Figueira placed at density of 150 and 225 seeds per square meter (Figure 4.), presented higher values for tiller ear mass, respectively. At density of 300 seeds per square meter, it was observed that there was no significant difference between cultivars for the analyzed variable. In addition, for the density of 375 seeds per square meter, the BRS 277 genotype was the only one that showed lower results than the others. 

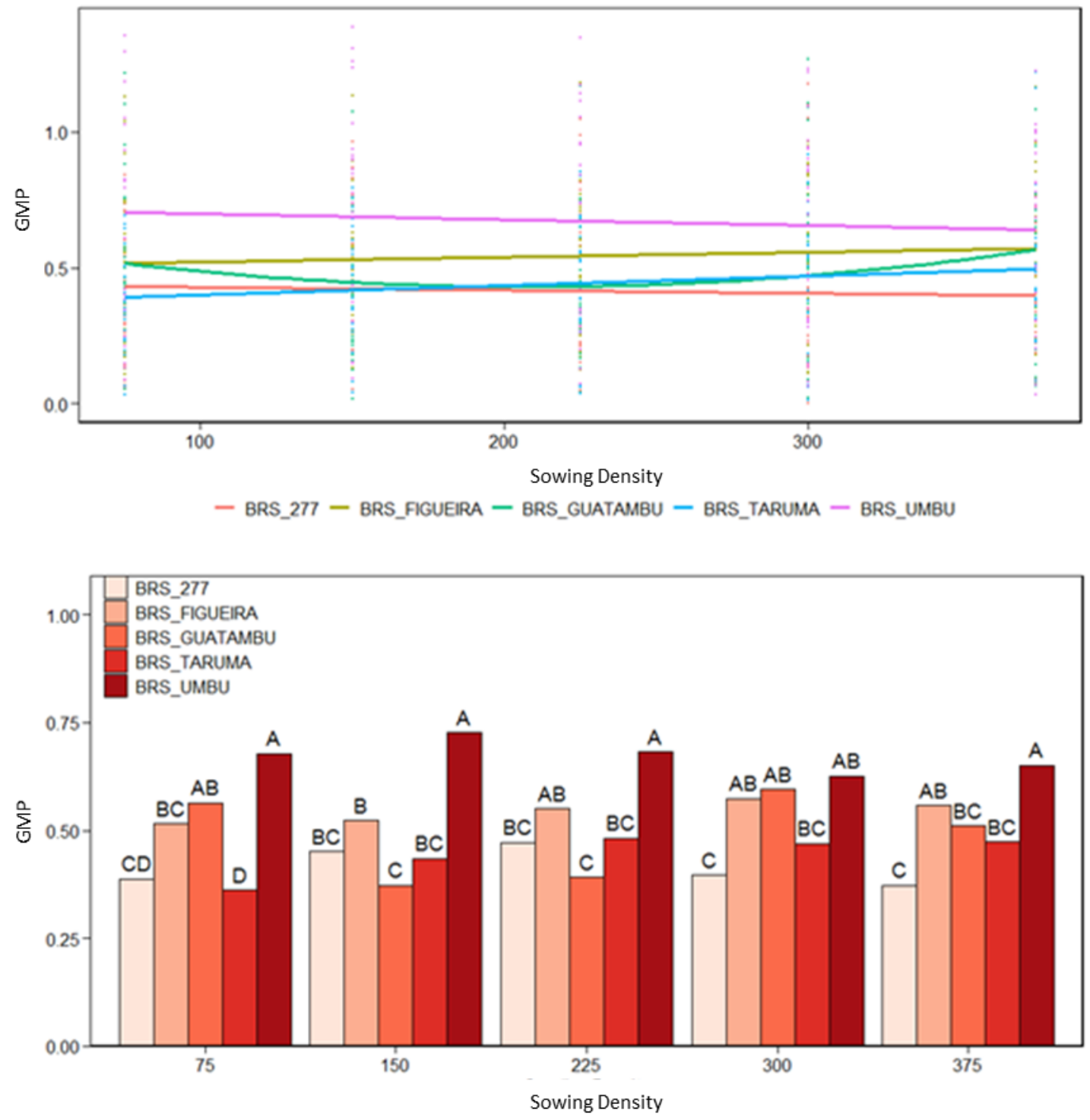

Figure 3. Effect of density on grain mass in the main plant and cultivar behavior. BRS $277 \mathrm{y}=$ $0.539 R^{2}$ : 0.01; BRS Figueira $y=0.534 R^{2}: 0.01$; BRS Guatambu $y=1,343-0,015 x+$ $0,00007 \mathrm{x}^{2}-0,0000001 \mathrm{x}^{3} \mathrm{R}^{2}$ : 0.09; BRS Tarumã $\mathrm{y}=-0.064 \mathrm{R}^{2}$ : 0.03; BRS Umbu $\mathrm{y}=$ $0.940 R^{2}$ : 0.01. Frederico Westphalen, Rio Grande do Sul State, Brazil, 2013/14. 

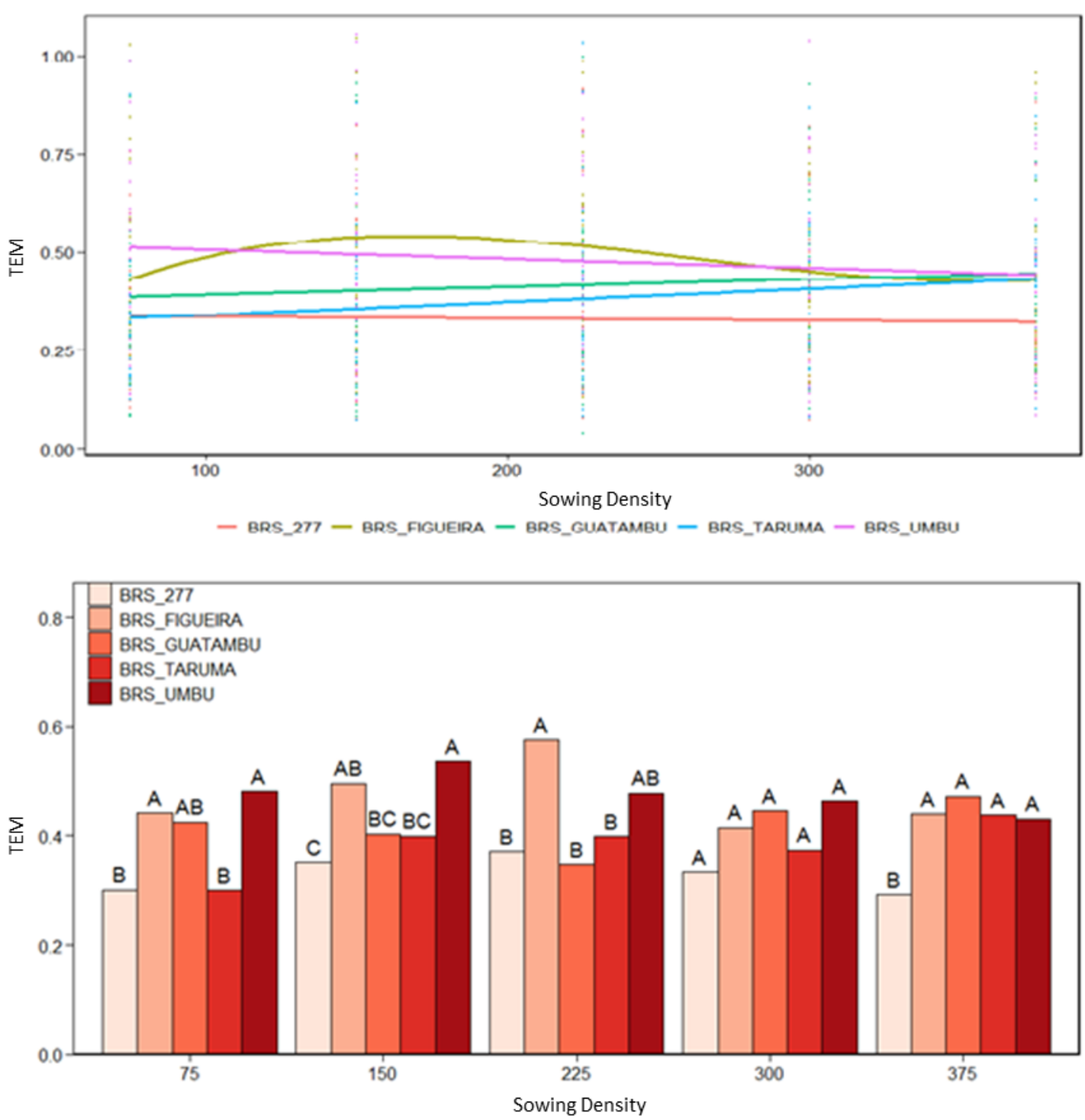

Figure 4. Effect of density on tiller ear mass and cultivar behavior. BRS $277 \mathrm{y}=0.352 \mathrm{R}^{2}$ : 0.01 ; BRS Figueira $y=1,645-0,333 x 0,003 x^{2}-0,000001 x^{3}-0,000000001 x^{4} R 2: 0.08 ; B R S$ Guatambu $y=0.047 \mathrm{R}^{2}$ : 0.04; BRS Tarumã $\mathrm{y}=0,304+0,0003 \mathrm{x} \mathrm{R}^{2}: 0.03$; BRS Umbu $\mathrm{y}=0,505 \mathrm{R}^{2}$ : 0.03. Frederico Westphalen, Rio Grande do Sul State, Brazil, 2013/14.

The BRS Umbu genotype had a small reduction in the tiller ear mass as the seed density increased, thus verifying a cultivar of high stability for the analyzed variables, due to the fact that it has less tillering capacity, the same stands out in comparison with the other genotypes.

The BRS Figueira genotype showed variation in the results of tiller ear mass, standing out from the others in densities with amplitudes greater than 100 up to close to 300 seeds per square 
meter. However, BRS Guatambu and BRS Tarumã had an increase in tiller ear mass due to the density increase. These cultivars showed the ability to provide tillers contributing to this result.

The cultivar BRS Umbu and BRS Figueira (Figure 5.) showed superiority in number of grains per ear in the tillers at densities of 75 and 150 seeds per square meter.
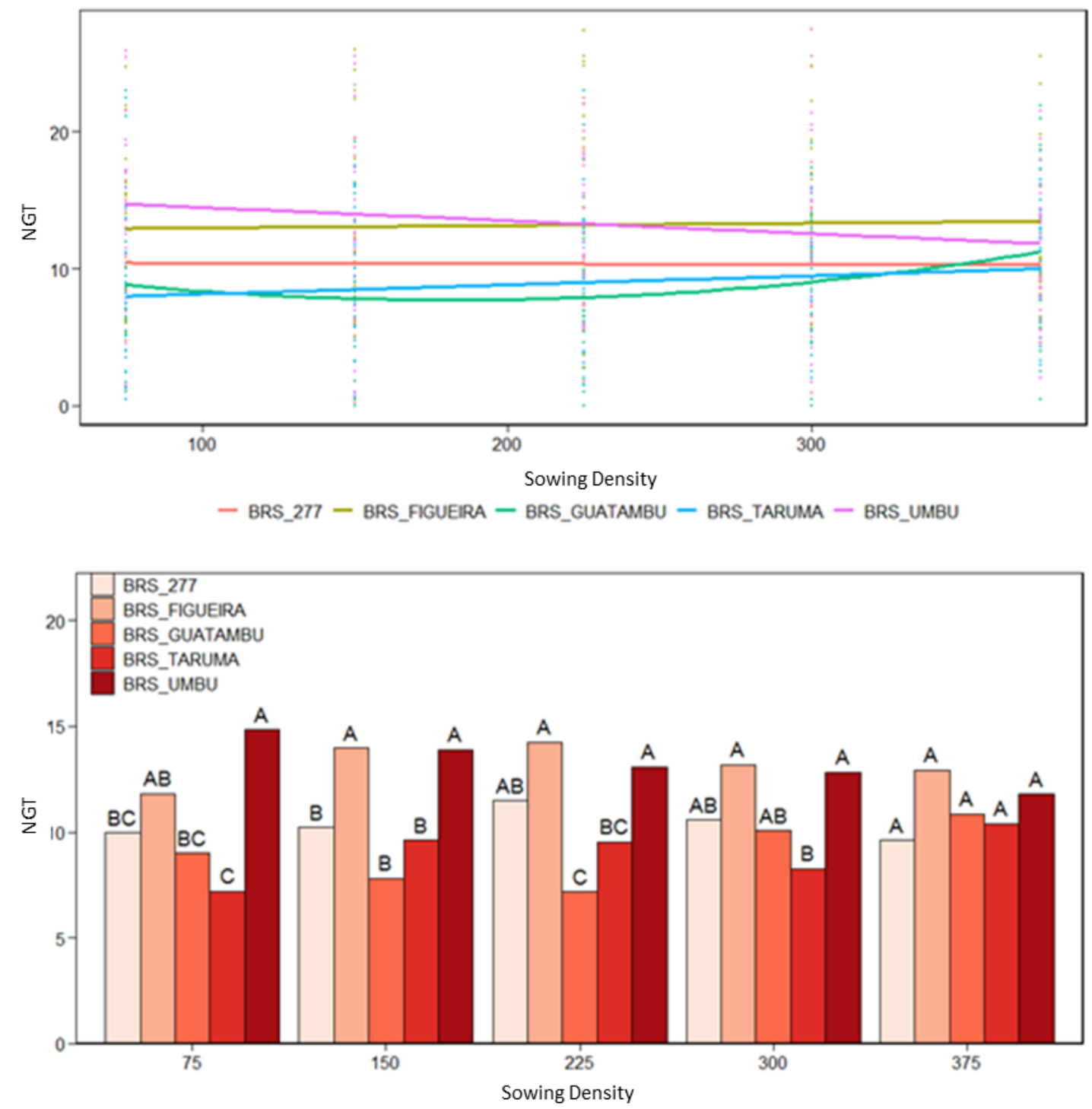

Figure 5. Effect of density on the number of grains per tillers and cultivar behavior. BRS Umbu $\mathrm{y}=23.675$; BRS Tarumã $\mathrm{y}=17.906$; BRS Guatambu $\mathrm{y}=41,270-0,399+0,001 \mathrm{x}-$ $0,000002 x \mathrm{R}^{2}$ : 0,08; BRS Figueira $\mathrm{y}=21.968$; BRS $277 \mathrm{y}=19.270$. Frederico Westphalen, Rio Grande do Sul State, Brazil, 2013/14. 
Together with BRS 277, they were superior in the density of 225 seeds per square meter, as well as all genotypes, except BRS Tarumã, obtained superior results when subjected to density of 300 seeds per square meter. Analyzing the treatment with higher seed density ( 375 seeds per square meter), it was observed that there was no significant difference between the genotypes for the analyzed variable. The results showed that the BRS Umbu genotype was superior to the variable analyzed at lower densities, with constant reduction as there was an increase in seeds per square meter. BRS Figueira expressed superior results compared to BRS 277, both were stable regardless of density for the analyzed variable, and may have phenotypic stability. BRS Tarumã and BRS Guatambu, on the other hand, showed an increasing relationship in the number of grains per tillers due to the increase in plant density.

The results obtained for ear length in main plants (ELP) and tillers (TEL) are observed (Figure 6.), a small variation was found as the density of plants increased, resulting in a variable that does not suffer influence and has no direct link to yield.
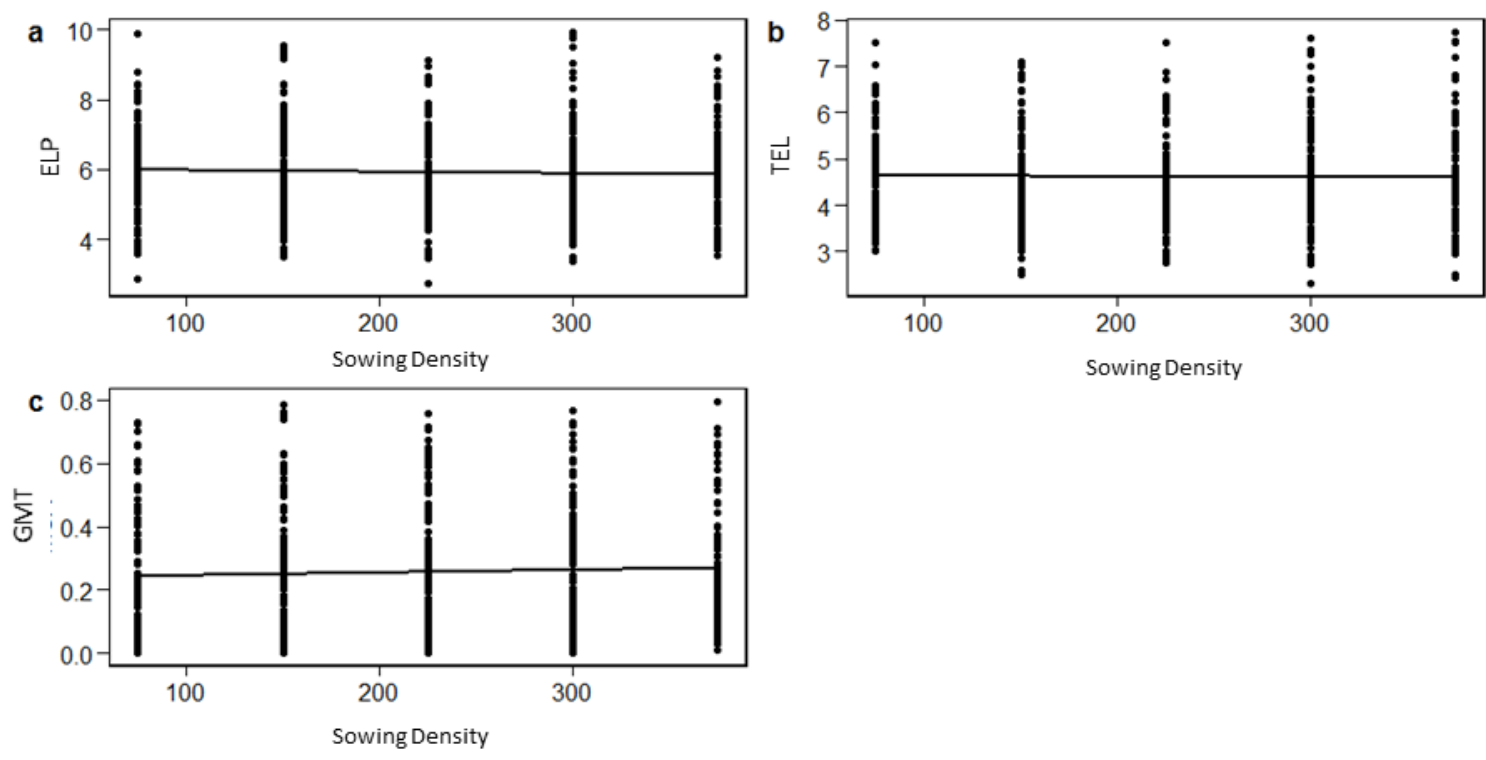

Figure 6. Main quantitative effects of ELP: ear length in the main plant $y=1,098+0.601 x$ R2 $\mathrm{r}$ : 0.77; TEL: tiller ear length; GMT: grain mass of tillers $y=0.02+0.48 \times \mathrm{R}^{2}: 0.53 \mathrm{r}: 0.72$. Frederico Westphalen, Rio Grande do Sul State, Brazil, 2013/14.

Teixeira Filho et al. (2008), in a study with plant densities higher than that of this work, concluded that the density of 400 seeds per square meter enabled a longer ear length compared to 500 seeds per square meter. For grain mass in tiller (GMT) there was an increment due to the 
increase in plant density, due to high densities reducing the number of tillers and consequently reducing the drains using the photoassimilates elaborated by the plant.

It was observed that ear length, ear mass, number of grains, and grain mass in the main plant are positively correlated with all the variables analyzed (Figure 7.). Likewise, the ear length, ear mass, number of grains on the ear, and grain mass on the tillers exhibit a positive correlation with all measured variables. According to Martin et al. (2010), the ear mass of the main plant correlates positively with the ear grain mass, since the straw index on the ear is low.

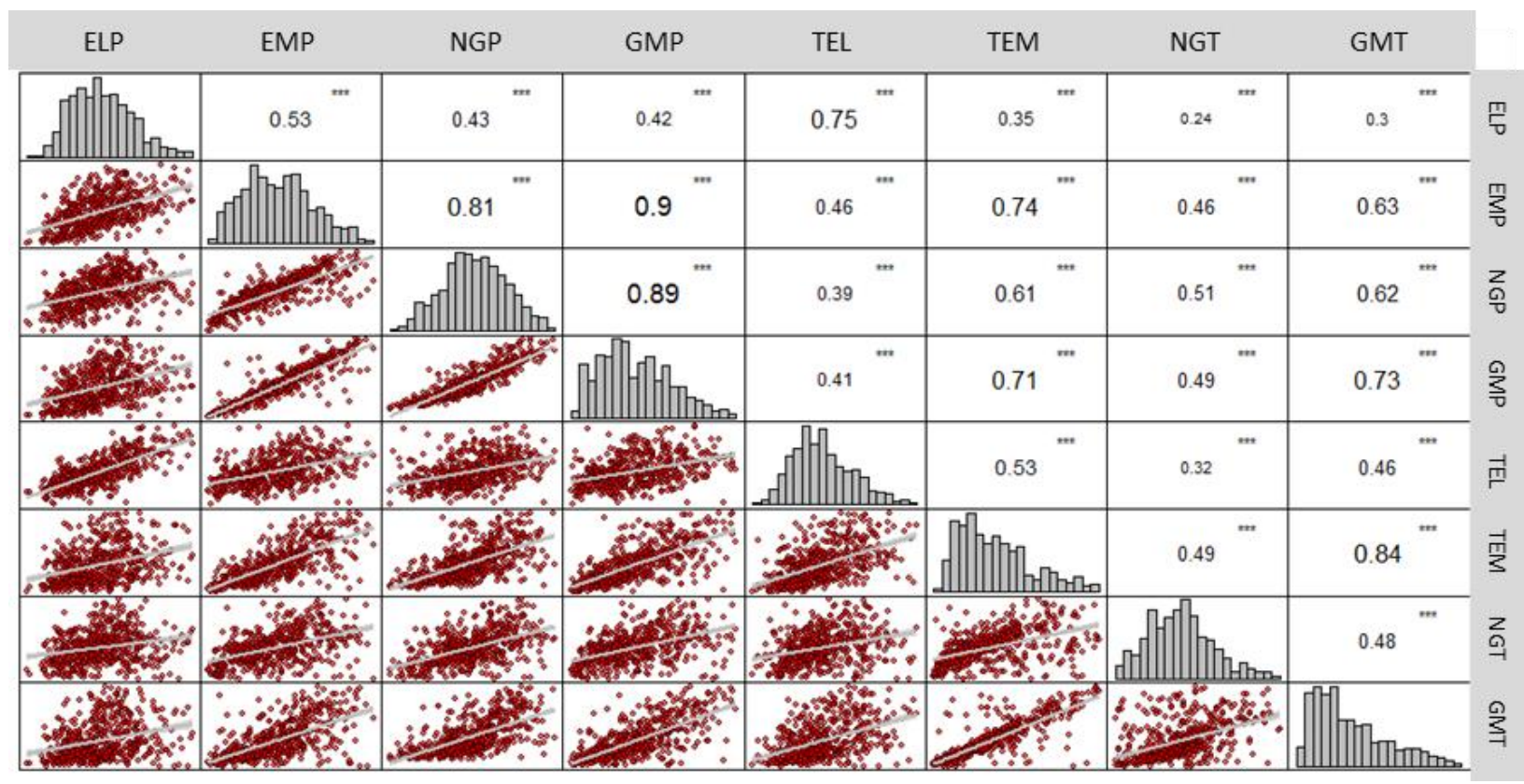

Figure 7. Estimates of Pearson's linear correlation for yield component characters. Frederico Westphalen, Rio Grande do Sul State, Brazil, 2013/14. Pearson linear correlation coefficients $(n=90)$ significant at $5 \%$ probability of error. ELP: ear length in the main plant; EMP: ear mass in the main plant; NGP: number of grains in the main plant; TEL: tiller ear length; TEM: tiller ear mass; NGT: number of grains on the tillers; GMT: grain mass in the tillers.

The BRS Guatambu genotype (Figure 8.) showed superior results for ear length in the mother plant and tiller ear length, verifying that both variables are positively correlated. For grain mass in the tillers, the cultivar BRS Umbu exhibit greater results than the other genotypes. 

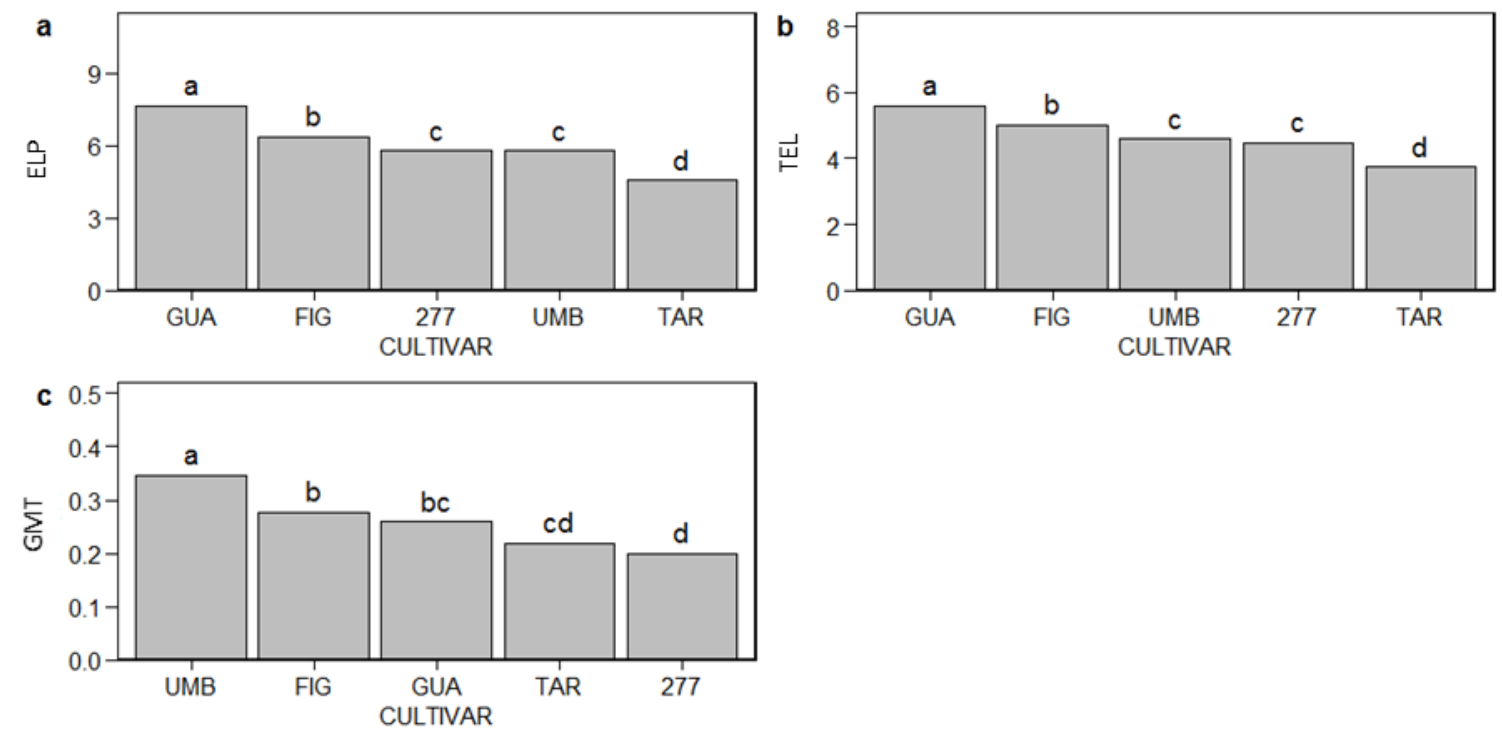

Figure 8. Main qualitative effects for cultivars. ELP: ear length in the main plant; TEL: tiller ear length; GMT: grain mass in the tillers. Frederico Westphalen, Rio Grande do Sul State, Brazil, 2013/14.

\section{CONCLUSION}

The yield components ear mass in the main plant, number of grains in the main plant, grain mass per main plant, tiller ear mass, and number of grains per tiller showed variations according to the interaction of cultivar with plant density. The components ear length in the main plant and in the tillers and grain mass in the tillers exhibit low dependence on density and cultivar. The cultivars BRS Tarumã, BRS Figueira and BRS Guatambu showed to be able to compensate the production in higher densities, increasing the values of some variables analyzed. All yield components show positive correlations.

The partition of photoassimilates was influenced by density, since the increase in the tillering capacity at low seed densities provided smaller mass of grain and ear in the tillers, indicating that the main plant has preference under photoassimilates partition.

\section{REFERENCES}

AISENBERG, G. R.; ZIMMER, G.; KOCH, F.; DELLAGOSTIN, S. M.; SZARESKI, V. J.; CARVALHO, I. R.; NARDINO, M.; SOUZA, V. Q.; PEDÓ, T.; MARTINAZZO, E. G.; VILLELA, F. A.; AUMONDE, T. Z. 2016. Biochemical performance, vigor and characteristics of initial growth of wheat plants under different sowing depths. International Journal of Current Research, Amsterdam, v. 8, n. 8, p. 6. 
ALVARES, C. A., STAPE, J. L., SENTELHAS, P. C., GONÇALVES, J. D. M., SPAROVEK, G., 2013. Köppen's climate classification map for Brazil. Meteorologische Zeitschrift, Sttutgart, p. 711-728.

BENIN, G.; CARVALHO, F. I. F.; OLIVEIRA, A. C.; MARCHIORO, V. S.; LORENCETTI, C.; KUREK, A. J.; SILVA, J. A. G.; CARGNIN, A.; SIMIONI, D. 2003. Estimativas de correlações e coeficientes de trilha como critérios de seleção para rendimento de grãos em aveia. Revista Brasileira de Agrociência, Pelotas, v. 9, n. 1, p. 9-16

CARVALHO, I. R., DE SOUZA, V. Q., NARDINO, M., FOLLMANN, D. N., SCHMIDT, D., BARETTA, D. 2015. Correlações canônicas entre caracteres morfológicos e componentes de produção em trigo de duplo propósito. Pesquisa Agropecuária Brasileira, Brasília, v. 50, n. 8, p. 690-697.

CARVALHO, I. R; NARDINO, M.; DEMARI, G.; SZARESKI, V. J.; AUMONDE, T. Z.; PEDO, T.; MONTEIRO, M. A.; PELEGRIN, A. J.; OLIVOTO, T.; FERRARI, M.; MEIRA, D.; SOUZA, V. Q. 2016. Biometry and genetic breeding of dual-purpose wheat. International Journal of Current Research, Amsterdam, v. 8, p. 3439-3454

GAYLER, S.; WÖHLING, T.; GRZESCHIK, M.; INGWERSEN, J.; WIZEMANN, H.; WARRACH-SAGI, K.; HÖGY, P.; ATTINGER, S.; STRECK, T.; WULFMEYER, V. 2014. A incorporação do crescimento dinâmico da raiz melhora o desempenho de Noah-MP em dois locais contrastantes de campos de trigo de inverno. Pesquisa de Recursos Hídricos, Estados Unidos, v. 50, n. 2, pág. 1337-1356

KEHL, K.; AISENBERG, G. R.; KOCH, F.; MONTEIRO, M. A.; SZARESKI, V. J.; CARVALHO, I. R.; NARDINO, M.; SOUZA, V. Q.; PEDÓ, T.; VILLELA, F. A.; AUMONDE, T. Z. 2016. Plant pre harvest desiccation and physiological performance of wheat seeds before and after storage. International Journal of Current Research, Amsterdan, v. 8, n. 9, p. 38456-38460

LLOVERAS, J., MANENT, J., VIUDAS, J., LÓPEZ, A., SANTIVERI, P. 2004. Seeding rate influence on yield and yield components of irrigated winter wheat in a Mediterranean climate. Agronomy Journal, Madison, v. 96, n. 5, p. 1258-1265

MINISTRY OF AGRICULTURE, LIVESTOCK AND SUPPLY. 2019. Projeções do Agronegócio: Brasil 2018/19 a 2028/29. Available at: http://www.agricultura.gov.br/ assuntos/politica-agricola/todas-publicacoes-de-politicaagricola/projecoes-doagronegocio/projecoes-doagronegocio-2018-2019-2028-2029/. Accessed on: Nov. 11, 2020.

MARTIN, T. N., SIMIONATTO, C. C., BERTONCELli, P., ORTIZ, S., HASTENPFLUG, M., ZIECH, M. F., SOARES, A. B. 2010. Fitomorfologia e produção de cultivares de trigo duplo propósito em diferentes manejos de corte e densidades de semeadura. Ciência Rural, Santa Maria, v. 40, n. 8, p. 1695-1701

MUNDSTOCK, C.M. 1999. Planejamento e manejo integrado da lavoura de trigo. Porto Alegre: Ed. do Autor, 228p.

OLSEN, J.; KRISTENSEN, L.; WEINER, J. 2006. Influence of sowing density and spatial pattern of spring wheat (Triticum aestivum) on the suppression of different weed species. Weed Biology and Management, Frederiksberg, v. 6, n. 3, p. 165-173.

OZTURK, A.; CAGLAR, O.; BULUT, S. 2006. Growth and yield response of facultative wheat to winter sowing, freezing sowing and spring sowing at different seeding rates. Journal of Agronomy and Crop Science, Berlin, v. 192, n. 1, p. 10-16

PELEGRIN, A. J.; CARVALHO, I. R.; NARDINO, M.; FERRARI, M.; SZARESKI, V. J.; BELlE, R.; MEIER, C.; WEBBER, T. A.; GUTKOSKI, L. C. SOUZA, V. Q. 2016. 
Technological quality of wheat under nitrogen management. International Journal of Current Research, Tamil Nadu, v. 8, p. 32932-32936.

ROY, S. K.; GALLAGHER, J. N. 1985. Production and survival of wheat tillers in relation to plant grow thand development. In: DAY, W.; ATKIN, R. K. (Eds). Wheat grow thand modelling. New York, p. 59-67.

STEDUTO, P., HSIAO, T. C., FERERES, E., RAES, D. 2012. Crop yield response to water. Rome: Food and Agriculture Organization of the United Nations.

TAVARES, L. C. V., FOLONI, J. S. S., BASSOI, M. C., PRETE, C. E. C., 2014. Genótipos de trigo em diferentes densidades de semeadura. Pesquisa Agropecuária Tropical, Goiânia, v. 44, n. 2, p. 166-174

TEIXEIRA FILHO, M. C. M., BUZETTI, S., ALVAREZ, R. D. C. F., DE FREITAS, J. G., ARF, O., DE SÁ, M. E. 2008. Desempenho agronômico de cultivares de trigo em resposta a população de plantas e a adubação nitrogenada. Científica, São Paulo, v. 36, n. 2, p. 97-106

USDA - United States Department of Agriculture. 2018. Production supply and distribution. (Stats commodity- Grains- Wheat). Foreign Agricultural Service, Washington.

VALÉRIO, I. P., CARVALHO, F. I. F. D., OLIVEIRA, A. C. D., MACHADO, A. D. A., BENIN, G., SCHEEREN, P. L.; SOUZA, V.Q.; HARTWIG, I. 2008. Desenvolvimento de afilhos e componentes do rendimento em genótipos de trigo sob diferentes densidades de semeadura. Pesquisa Agropecuária Brasileira, Brasília, v. 43, n. 3, p. 319-326 